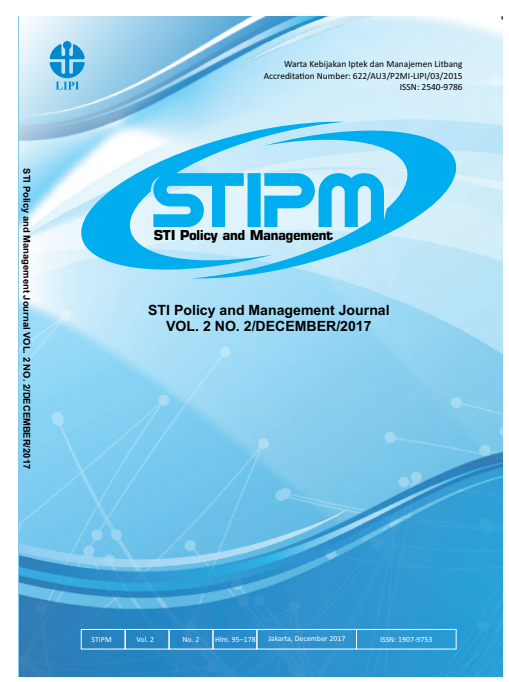

Journal of STI Policy and Management

Publication details, including instructions for authors and subscription information: http://www.stipmjournal.org/

\title{
Key Success Factors of Renewable Energy Projects Implementation in Rural Areas of Indonesia
}

\author{
Wati Hermawati and Ishelina Rosaira \\ Research Center for Science and Technology Development, Indonesian \\ Institute of Sciences \\ Version of record first published: 15 December 2017
}

To cite this article: Hermawati, W. and Rosaira, I. (2017). Key Success Factors of Renewable Energy Projects
Implementation in Rural Areas of Indonesia. Journal of STI Policy and Management, 2(2), 111-125
To link to this article: http://dx.doi.org/10.14203/STIPM.2017.122

ISSN 2540-9786 (Print); ISSN 2502-5996 (online)

Accreditation Number: 622/AU3/P2MI-LIPI/03/2015

Full terms and conditions of use: https://creativecommons.org/licenses/by-nc-sa/4.0/

You are free to:

- Share : copy and redistribute the material in any medium or format

- Adapt : remix, transform, and build upon the material

- The licensor cannot revoke these freedoms as long as you follow the license terms.

Under the following terms:

Attribution - You must give appropriate credit, provide a link to the license, and indicate if changes were made. You may do so in any reasonable manner, but not in any way that suggests the licensor endorses you or your use.

$\$$ NonCommercial - You may not use the material for commercial purposes.

(2) ShareAlike - If you remix, transform, or build upon the material, you must distribute your contributions under the same license as the original.

No additional restrictions - You may not apply legal terms or technological measures that legally restrict others from doing anything the license permits.

Notices:

- You do not have to comply with the license for elements of the material in the public domain or where your use is permitted by an applicable exception or limitation.

- No warranties are given. The license may not give you all of the permissions necessary for your intended use. For example, other rights such as publicity, privacy, or moral rights may limit how you use the material.

- If you copy the dataset merely to extract the uncopyrightable data elements would not need permission to do so. However, if you republish the full dataset or using the copyrightable data layers require a permission from PAPPIPTEK-LIPI. 


\title{
JOURNAL OF SCIENCE, TECHNOLOGY AND INNOVATION POLICY AND MANAGEMENT (STIPM JOURNAL), Volume 02, Number 02, December 2017
}

\author{
FOREWORD by EDITOR-in-CHIEF
}

We are pleased to present the STIPM Journal Vol. 2, No. 2, December, 2017. This issue brings together research findings on the adoption of science, technology, and innovation policy and management from Thailand, Malaysia, and Indonesia. This issue also presents a theoritical review on the determinants of enterpreneurial success.

In the original articles of this issue, Poolsak Koseeyaporn et al. presented the Talent Mobility Programme in Thailand. It is a new programme for making relationship between the researchers, who are mostly working at Public R\&D institutions and universities/higher education institutions, and companies. This programme is supporting the researchers to connect, meet, and explore the possibility of having research topics that fulfill both interests of researchers and the companies. The researchers would have a chance to be exposed to the industry's research problems as well as to obtain a level of trust from the companies.

Wati Hermawati and Ishelina Rosaira present the result of an exploratory study on the factors contributing to the sustainability of renewable energy projects in the rural areas. It was indicated that the success of energy technology implementation lays not only in good technology performance and long-term maintenance, but was also highly dependent on six key factors, namely (1) project planning and development; (2) community participation; (3) active communication and beneficiaries; (4) technology maintenance, including workshop and technician availability; (5) project management and institutionalisation; and (6) local government support and networks. The findings from this study provide useful insights to all stakeholders involved in the implementation of renewable energy technology for the rural areas in Indonesia.

Thiruchelvam presents a brief overview on Malaysia's STI achievements, salient features of the nation's national innovation system (NIS), and the key challenges of its NIS. The central theme of the paper is that success in STI is not automatic. It must be made through effective policies in promoting innovation as well as innovations in policy-making itself. Without such commitment for these two sides of innovation policy-making, pouring more resources to the development of STI will be futile.

Ria Hadiyati, et al., discussed the innovation capacity-building in the health sector in Indonesia. Current initiatives to enhance innovation capacity exists by intensifying R\&D consortia in life science, especially vaccine and stem cell. The research capacity in the area of vaccines has been long started from individual research conducted by researchers. It has been continued into research organisations, and then developed into building innovation capacity through R\&D consortia. In areas of stem cell, there is still lack of evidence however, efforts have been made to build innovation capacity through R\&D consortia.

Emyana Ruth and Faiq Wildana compare the management of Indonesian ICT Business Incubators from the perspective of administrators and tenants. The incubation administrators emphasise the 
importance of aspects of skill development, synergy, and seed capital. Meanwhile, from the tenants' perspective, skill development services are considered quite satisfying, either in government, private, or university-owned business incubators. However, emphasising on skill development aspect might lead incubators to provide oversized portion on training activities and susceptible to be trapped as a training institute.

Dyan Vidyatmoko and Pudji Hastuti propose a theoretical framework as a result of the development of theoretical framework, proposed by Kiggundu as well as Lussier and Halabi. The proposed framework is to examine factors affecting the success of entrepreneurship development in Indonesia. Three factors are discussed simultaneously, namely the entrepreneurs, the entrepreneurial firms, and the external environment. Success is represented by three indicators consisting of employment growth, profitability, and survival. Compared to both models, the proposed approach is expected to provide a comprehensive analysis of the factors affecting the success of entrepreneurship development in Indonesia. The results of the study is relevant and useful, both from the academic and practical points of view. It also has practical contribution for policy makers in terms of conceptualising and operationalising appropriate factors for the success of entrepreneurship in Indonesia.

After indexing by Google Scholar, ISJD, and IPI, STIPM Journal is now indexed with DOAJ, BASE, and OCLC World Cat. This has made the journal dissemination wider. We would like to thank all the reviewers for their excellent work and the authors who have kindly contributed their papers for this issue. We are also indebted to the STIPM Journal editorial office at Pappiptek LIPI and the publishing and production teams at LIPI Press for their assistance in the preparation and publication of this issue.

We expect that STIPM will always provide the highest scientific platform for the authors and the readers, with a comprehensive overview on the most recent STI Policy and Management issues at the national, regional, dan international levels.

Jakarta, December 2017

Editor-In-Chief 



\section{JOURNAL OF STI POLICY AND MANAGEMENT}

Volume 2, Number 2, December 2017

\section{LIST OF CONTENTS}

An Empirical Study of Policy Implementation of Thailand Talent Mobility Programme

Poolsak Koseeyaporn, Kittisak Kaweekijmanee, Arum Kitipongwatana,

and Oraphan Wiarachai

Key Success Factors of Renewable Energy Projects Implementation in Rural Areas of Indonesia

Wati Hermawati and Ishelina Rosaira

Mobilizing Science, Technology and Innovation (STI) for Socio-Economic Development:

The Experience of Malaysia

K. Thiruchelvam

Building Capacity for Innovation through R\&D Consortia in Health Projects: From Network Interaction to Systemic Transformation

Ria Hardiyati, Trina Fizzanty, and Erman Aminullah

Management of Indonesian ICT Business Incubators: Administrators' Compared to Tenants' Perspective

Emyana Ruth E. Sirait and Faiq Wildana 149-161

SCIENTIFIC REVIEW

The Determinants of Entrepreneurial Success: A Multidimensional Framework

Dyan Vidyatmoko and Pudji Hastuti. $163-178$ 


\title{
it STI POLICY AND MANAGEMENT

\section{Key Success Factors of Renewable Energy Projects Implementation in Rural Areas of Indonesia}

\author{
Wati Hermawati ${ }^{1}$, Ishelina Rosaira ${ }^{2}$ \\ ${ }^{1,2}$ Research Center for Science and Technology Development, Indonesian Institute of Sciences
}

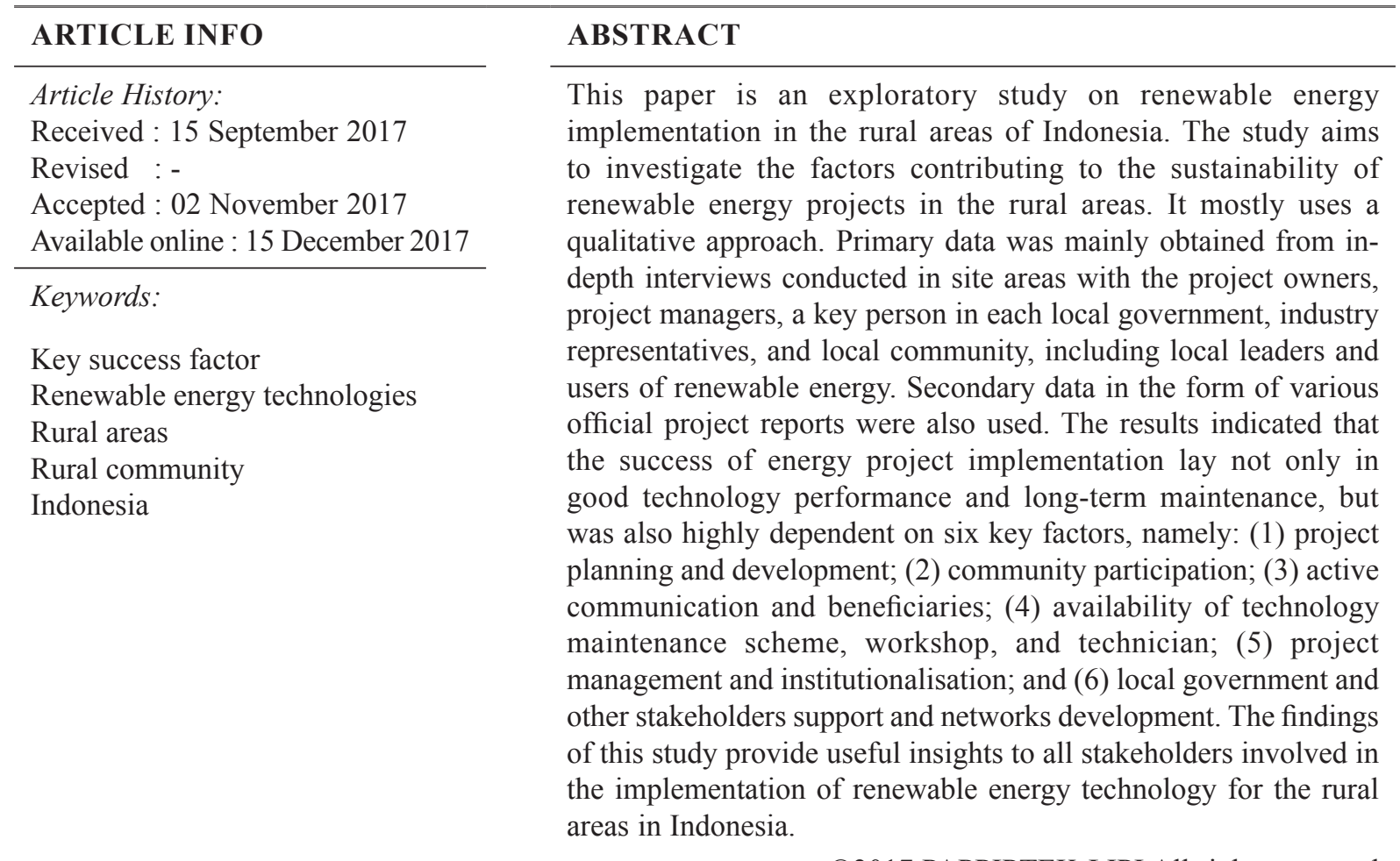

C2017 PAPPIPTEK-LIPI All rights reserved

\section{INTRODUCTION}

\section{A. Background and Objective}

Understanding the factors related to the existing implementation of renewable energy technologies in rural areas of Indonesia will contribute to many energy projects and initiatives. These

\footnotetext{
* Corresponding Author.

E-mail:wherma2007@yahoo.com
}

initiatives are usually implemented by many stakeholders, including private companies, universities, government and nongovernment institutions, as well as donor or international agencies. The understanding contributed by this study is more focused on several key issues in establishing energy sustainability in rural areas, as well as in providing potential solutions for rural development. At present, many of the rural energy projects only operate for less than one 
year; most of the problems encountered are not directly related to energy technologies, but are mostly related to lack of skill in technology maintenance, lack of management capability, lack of community awareness towards energy projects, etc. (Hermawati, Thoha, Grace, \& Rosaira, 2010; Sambodo, 2015).

In rural and remote areas, provision of clean energy, especially for domestic needs, such as for cooking and lighting, is not easily available. The World Bank (2013) reported that approximately $40 \%$ (about 24.5 million) of Indonesia's households is located mainly in rural areas. These households still rely on traditional cook-stoves and biomass (mainly fuelwood) in their primary cooking. Furthermore, until the end of 2015, 12,659 villages (out of 74,715 total villages in Indonesia) have no electricity (MEMR, 2016). Although Indonesia's national electrification ratio has increased from $43 \%$ in 1995 to $84.1 \%$ in January 2015 (ADB, 2015), regional disparities exist. The province of Papua and East Nusa Tenggara have the lowest electrification ratios (only about 1 out of 3 households have electricity). In 2015, the electrification ratio in Papua was only $45.93 \%$.

Many of the villages in these areas have potential renewable energy resources, such as biomass, water, wind, and solar. However, private investment in energy infrastructure development for villages in remote areas and small islands is very rare. In many countries, studies show that many consider energy for rural communities to not be an economically viable business (Tharakan, 2015; Radhakrishna, 2012; Hermawati, et al., 2010). Like many other countries, challenges in having renewable energy project in these areas are related to geographical conditions, human resources capacity, funding, etc. (Schmidt, Blum, \& Wakeling, 2013; Magnoni \& Bassi, 2009). Therefore, to overcome these challenges, the central and local governments should provide more support for developing renewable energy and its infrastructures (Hermawati et al., 2010).

The lesson learned from several villages in remote areas, such as in the provinces of East Jawa and West Nusa Tenggara where the stateowned electricity company (PLN) does not exist, is that the provision of self-managed renewable energy, in particular electricity, brings improvements to the economy of households and also that of the community as a whole (Hermawati \& Darmajana, 2010). Since renewable energy produces clean energy, their utilisation can also be one climate change mitigation strategy in rural areas (Schmidt et al., 2013; Herran \& Nakata, 2008; Schneider, Schmidt, \& Hoffmann, 2010; De-Xin, 2016). Besides, many studies also indicate that the success of the energy project in rural areas has brought many improvements in the daily life of inhabitants of rural areas, such as:

1) increased access to affordable clean energy in rural areas, as well as increased village ratios of households with energy;

2) stimulation of social and economic development, improvements in the perfomance of basic education for children under 12 years old, and improvements in health quality for inhabitants;

3) improvements in the ability to self-managed energy in rural areas, as well as energy security through energy self-supply;

4) the creation of energy trade with other villages and the local PLN;

5) the creation of more business and more innovation in products, practices, and policies in rural areas;

6) increased awareness of the significance of maintaining a sustainable and healthy environment (Carlisle, Elling, \& Penney, 2008; EEP Indonesia, 2014; Heaslip, Costello, \& Lohan, 2016; OECD, n.d).

However, regardless of the wide-ranging benefits of the successful energy projects, deducing influential factors in the implementation of renewable energy technologies in the rural areas of Indonesia is one of the primary concerns of all stakeholders, including local government or implementors of energy technology for rural communities in Indonesia.

Therefore, for the effectiveness of renewable energy technology projects, energy stakeholders, including local governments, need to be informed of what the influential factors in the implementation and management of renewable energy technologies in the rural areas of Indonesia are, so 
the implementation of renewable energy projects can be done effectively and can meet the needs of the locals. Therefore, the main objective of the study is to identify the influential factors in the implementation and management of renewable energy technologies in the rural areas of Indonesia. This study also can enrich the renewable energy studies.

\section{B. Methodology}

A descriptive qualitative method was used in this study. Major sources of study came from focus group discussions at the local government and local community levels, in-depth interviews with project stakeholders, and field observations in the research areas. Participatory approaches were also practiced during this study (Jackson and Kassam, 1998, p.1). The researchers investigate factors influencing the success of renewable energy technologies implementation in rural areas. In this study, the researchers also include gender issues within the context of renewable energy options for sustainable rural development.

Field observations were conducted during March, April, and June 2015. Interviews and discussions were conducted with 60 respondents (including more than one of participant from each institution from personnel of Ministry of Energy and Mineral Resources (MEMR), local government institutions, and international donors/ funding agencies; heads of NGOs; users and owners of micro and small businesses; managers of cooperatives; manager and technician of micro hydro project; spare parts workshops, technicians of wind power, biogas, and solar energy technology; and community and religious leaders in the villages) as part of the primary data gathering component. Focus group discussions were conducted at least once in each district with about 8 to 15 participants from various institutions and representations from local community. Of the 60 respondents, about 45 (20 women and $25 \mathrm{men}$ ) were interviewed. Secondary documents were made available by the respondents or data were obtained with consent.

Content analysis was used for both comprehensive results of primary and secondary data gathering. Then, a descriptive analysis was presented to identify and describe the influential factors in making the renewable energy implementation projects successful and sustainable.

Types of renewable energy technology projects for rural areas, among others, are microhydro and wind energy technology, biogas, improved cook-stoves, and solar photovoltaic. The implementation of each projects were funded by various institutions, such as the government, nongovernment organisations (NGOs), international agencies (donor agencies), and parts of the industry concerned with rural livelihood improvement in Indonesia.

The study took place in two villages (Senduro and Bruno) in Lumajang District, East Java Province; two villages (Sami Galuh and Bleder) in Kulon Progo District, Yogyakarta Province; two villages (Lantan and Selojan) in West Lombok District, West Nusa Tenggara Province; two villages (Habaring Hurung and Petuk Bukit) in Palangkaraya District, Central Kalimantan Province; and one village (Kamanggih) in Southeast Sumba District, East Nusa Tenggara Province. The implementers of renewable energy technology among others are MEMR, the local governments, NGOs, and the state-owned electricity company (PT PLN). See Appendix I.

\section{ANALYTICAL FRAMEWORK}

At the beginning, Indonesia's fuel subsidies (electricity and fossil fuels) were put in place to make energy more affordable, particularly to poor people. However, further on, this situation has made it harder for renewable energy systems to compete economically, even though its potential is indispensable as shown in Appendix II.

Renewable energy systems are therefore most likely to be installed in rural areas or remote islands, where it is difficult and expensive to transport fossil fuels and where there is no grid-connection. Renewable energy systems in rural areas are most likely off-grid schemes. Like many other countries, types of renewable energy that exist in rural areas of Indonesia, among others, are microhydro, bioenergy, wind power, solar photovoltaic, and biogas (EEP Indonesia, 2014; Pillai, 2014). In order to fulfil energy requirements, various forms of energy (light, heat, 
mechanical power, and electricity) are needed by the community, as shown in Appendix III. There are several sectors in rural areas which demand energy, including household, farming, industry, offices, shops, transportation, and community services (such as schools, health centres, water pumping, street lighting, etc.).

\section{A. Rural community as users and producers of renewable energy}

A rural community is a group of inhabitants of a rural area. Rural communities typically have smaller populations and the majority of the people have livelihoods associated with local resources, such as agriculture, forest, farm or livestock. According to Tomc and Vassallo (2015), 'community' is a concept with many and various meanings and varied purposes. Within the context of energy, as Walker and Devine-Wright (2008), and Walker, Devine-Wright, Hunter, High, and Evans (2010) described, 'community' should be seen not only as users of energy, but also as actors in managing renewable energy technology, including selling electricity in the form of off-grid or on-grid schemes.

As users of renewable energy, the term 'community' is usually associated with households. Lighting and cooking are the energy most commonly used by households. Other users of energy in rural areas are micro, small, and medium enterprises. Electricity is also used by public facilities such churches, mosques, public meeting rooms, village offices, street lighting, etc.

Whereas Oteman, et al. (2014) point out that community initiatives for renewable energy include promotion of the production and consumption of renewable energy. Similarly, Walker and Devine-Wright (2008) mention that renewable energy projects can be categorised as community projects where the selected local community is actively involved in producing and managing renewable energy. In Indonesia, the groups in local communities managing the projects usually have legal authority, such as cooperatives (Hermawati \& Darmajana, 2010).

\section{B. The challenges of renewable energy community projects implementation}

Previous research shows that community participation is necessary to ensure the success of a renewable energy community project, particularly in delivering the services provided, such as electricity, improved cook-stoves, or communal biogas (Tomc and Vassallo, 2015; Walker and Devine-Wright, 2008; Carlisle et al., 2008). The community project is important. It is through the project that the community is willing to share ideas and opinions so that their needs and expectations are known. Often, community projects also deliver some innovative ideas from the community. Good renewable energy community projects will involve good responsibility and a sense of ownership, as the community would also feel that they are also involved in a project. Energy community projects are also about solidarity, mutual trust, and peace (Sui, 2013). According to Oteman et al. (2014), community energy projects take either an agency-oriented focus or a structure-oriented focus in terms of their occurrence and the opportunities they provide, and most community projects acknowledge the importance of (bio) physical characteristics, as shown in Table 1.

Academics argue that the success of community projects stem from the community acceptance and societal integration of sustainable energy technologies. While many discuss the relatively low investments and equity in renewable energy projects, the social aspects of community renewable energy should also receive serious attention as technical factors. The main challenges lie at several factors, such as community engagement (Hoffman \& High-Pippert, 2010; Alvial-Palavicino, Garrido-Echeverría, Jiménez-Estévez, Reyes, and Palma-Behnke, 2011), financial participation (EEP, 2014), the fostering of trust between stakeholders in the development process in order to achieve a more collaborative community energy project (Walker, Devine-Wright, Hunter, High, and Evans, 2010; Büscher \& Sumpf, 2015), and community attitudes and perceptions (Rogers, J.C., Simmons, E.A., Convery, I., Weatherall, A. 2008). 
Table 1.

The Key Success of Community Renewable Energy Initiatives

\begin{tabular}{lll}
\hline Type & Dimension & Characteristics \\
\hline Strategic & Cultural & $\begin{array}{l}\text { Legitimacy of sustainability objectives, pro-environmental at- } \\
\text { titude, willingness to act }\end{array}$ \\
\hline & Organisational & Support for community action \\
\hline Personal & $\begin{array}{l}\text { Leadership, knowledge and expertise, access to technology and } \\
\text { grid, adaptive capacity, management skills }\end{array}$ \\
\hline Political & $\begin{array}{l}\text { Subsidies, flexibility, priority for sustainability goals, project sup- } \\
\text { port (advice, financial), network }\end{array}$ \\
\hline Legal & $\begin{array}{l}\text { Formal rules and regulations, decision-making procedures, de- } \\
\text { gree of discretionary space, control mechanisms }\end{array}$ \\
\hline Economic & $\begin{array}{l}\text { Division of material resources, availability of investors, expected } \\
\text { profitability }\end{array}$ \\
\hline Socio-cultural & $\begin{array}{l}\text { Capacity for institutional learning, problem perception, attitude } \\
\text { on experimentation }\end{array}$ \\
\hline (Bio-)physical & $\begin{array}{l}\text { Wind speed, solar hours, tidal waves, hydropower, presence of } \\
\text { fossil fuels, urbanisation, technological developments }\end{array}$ \\
\hline
\end{tabular}

Source: Oteman, et al. (2014)

Moreover, ADB (2015) mentioned that setting electrification standards, creating a plan, budgeting for public investment, and establishing targets are therefore steps in an iterative process of creating an energy project in rural areas, as shown in Figure 1.

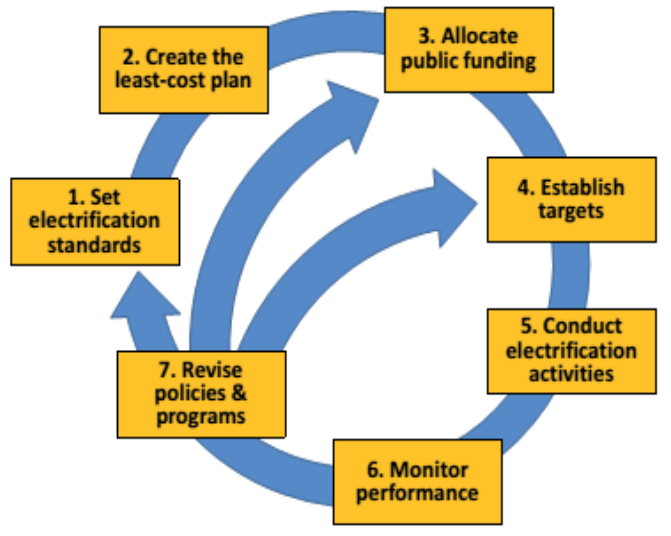

Source: ADB (2015)

Figure 1. Electrification Planning and Implementation as an Iterative Process

Following monitoring and evaluation of electrification activities conducted by the management team of the project, the government may make changes in electrification policies and programs, modify the level of public funding, or amend electrification targets. Nevertheless, this study focuses more on the key factors supporting the sustainability of renewable energy projects in rural areas, especially to fulfil the achievement of universal electricity access in 2020. Many experiences show that renewable energy is often found to be the most cost-efficient (least-cost) source of supply for off-grid systems (ADB, 2015).

\section{CASE STUDY FINDINGS}

Five types of renewable energy technologies are being implementing in many rural areas of Indonesia, namely microhydro, innovative cook stoves (TSHE), biogas, solar photovoltaic, and wind turbine. Case study findings show that every technology has similar schemes in the implementation process. Therefore, the key success factors for each technology are almost similar.

\section{A. Microhydro project}

Two microhydro projects in two provinces were chosen as sample of this study. The first sample was in Subang Regency, West Jawa Province, with the capacity of microhydro $100 \mathrm{~kW}$. This project was implemented by NGO A. The project is known as private-public partnership (PPP) program with funding of the project came from international donor agency, PT H and NGO A as private entities. In the first stage of its implementation (2004), this microhydro was managed by NGO A and later on a cooperative was built to manage the microhydro project with the technical assistance from NGO A. At present, most of the 
electricity resulted from microhydro was sold to PLN (public electricity company) or known as on-grid scheme, only a small percentage was used directly to electrify a few households, particularly the very poor households, or known as off-grid scheme.

The second microhydro project was in Lumajang Regency, East Jawa Province. The capacity of microhydro is about $36 \mathrm{~kW}$. Funding of the microhydro came from the community. This community project was implemented in 1990. All electricity resulted from microhydro is sold to about 120 households in the nearby microhydro area (off-grid). The microhydro is managed by a community group called 'Paguyuban PLTMH'. Customers paid all their electricity bills to this organisation. Price of microhydro electricity per kilowatt hours $(\mathrm{kWh})$ is cheaper than the electricity price from PLN. However, the quality of microhydro electricity is lower than that of PLN.

In both places, in addition to lighting, electricity from microhydro is also used for operating micro and small businesses. Many women sell foods such as cassava and taro chips and other types of processing foods using electronic home appliances, such as rice cooker, blender, mixer, etc. Men also doing their home businesses by using electricity such as having services of motorcycle and other electrical appliances. There are also clothing convection run by a group of households, and a few men are doing their business to become tailors.

The researchers identified that the sustainability of microhydro in both places was due to well planed and good feasibility study that was conducted by the project owner and the implementer. There was a good community participation and communication in all stages of the projects.

The project's owner also provides technical assistance, including developing microhydro management for certain period of time, although technical assistance is still provided until now. Various trainings were also provided for the community at the beginning of the project, including management, business, and other skills trainings. The project also has increased community aware- ness on work collaboration among themselves and also people from outside.

\section{B. Innovative cook stove}

Innovative cook stove - more popular in Indonesia as Tungku Sehat Hemat Energi (TSHE -clean and energy efficient cook stove)-project was implemented in Kulonprogo Regency, Province of D.I. Yogyakarta and in Palangka Raya, Central Kalimantan by NGO Y. There are two villages in Kulonprogo and two villages in Palangka Raya, where almost all households still use traditional stove with firewood, because firewood is more accessible and affordable in many rural areas including in these villages compared to LPGs.

Most families make their own stoves from mud, cement or stone that are energy-inefficient and produce much toxic smoke. Using traditional stove is also time-consuming, can lead to a serious health risk and causes dirty kitchen. Unaware of the harmful effects of household air pollution, users of firewood stoves expose themselves daily to toxic smoke, increasing risks for asthma, lung tuberculosis, and acute respiratory infections, particularly amongst children.

Since 2008, implementation of TSHE has been conducted by NGO Y in cooperation with local farmer's association. About $70 \%$ of the total households in 4 villages chosen as sample of this study (140 households) has changed their traditional stove to TSHE. Some of the TSHE using local resources were made by themselves with the technical assistance provided by NGO Y. Several TSHE were bought from local stove craftsmen. The local stove craftsmen have attended stove skills trainings held by NGO Y. The revolving fund schemes for TSHE were also introduced to the community in these villages.

The user of TSHE is not only common households, but also about 54 sugar palm micro and small businesses. The sustainability of using TSHE in these villages is due to several factors, such as (1) good feasibility study and good communication among TSHE stakeholders and community; (2) users' orientation in improving health and time savings for households; (3) easy maintenance and free technical assistance provided by NGO Y; (4) forests and associated ecosystem 
services preservation; and (5) emissions reduction to minimise global climate change. Despite the purported economic benefits of such technologies, however, progress in achieving large-scale adoption and use has been remarkably slow. Users of TSHE are mostly households in rural areas with poor economic condition. Therefore, price is considered as main criteria in replacing their traditional stove as compared to being inconvenient used or culturally inappropriate matters.

\section{Biogas}

One of the famous biogas programmes in Indonesia is the Indonesian Domestic Biogas Programme (or known as the BIRU programme; an acronym of Biogas Rumah, or 'biogas for the home'). Hivos and SNV are initiaves of BIRU program in Indonesia. At present, BIRU program was implemented by an NGO called Yayasan Rumah Energi (YRE). BIRU was started in May 2009 with financial support from the Netherlands Embassy and as of November 2015, has built 20,150 biogas digesters in ten provinces in Indonesia.

East and West Jawa Province and Sumba Island are taken as sample of this study. In this province, BIRU programme was started on 15 May 2009. Total home biogas installed until December 2016 was about 7,653 units (plants) in East Jawa Province. Since there are many cattles in this area, biogas are produced from cow manure in East and West Jawa Province, while in Sumba Island are from pig manure. Sustainability of biogas adoption is quite high in these areas. Since biogas is managed by individual household, husbands and wives or other family members must attend biogas training. The trainings include management and maintenance of biogas as well as instructions to use biogas. Almost all farmers of dairy cattle (with minimum 2 cows) and households with 4 pigs have at least one biogas sized $4 \mathrm{~m}^{3}$. Users of biogas at households scale are mostly women. There are several benefits of home biogas leading to the sustainability of using it as follows.

1) Saves fuel wood - efficient way of energy conversion and it is a non-polluting and renewable source of energy.
2) Saves women and children from drudgery of collecting and carrying of firewood, exposure to smoke in the kitchen, and time consumed for cooking and cleaning of utensils, so there is an improvement in environment, sanitation, and hygiene.

3) Produces enriched organic manure, which can be used as fertilizers and replace chemical fertilizers.

4) Leads to employment generation in the rural areas, such as having organic business, becoming a mason or biogas builder, etc.

5) Benefits environmentally on a global scale. Biogas plants significantly lower the greenhouse effects on the earth's atmosphere. Therefore, the plants have lower methane.

Since the begining, BIRU project has highly involved the farmers of dairy cattle. Monitoring and evaluation were done on a regular basis and Hivos partners provide trainings on biogas, business management, and other skills training.

\section{Solar photovoltaic}

Solar photovoltaic installation for selfconsumption of households, elementary school, and grinding corn house in West Lombok and Sumba Island, Indonesia, was conducted in 2014. Currently, solar phoyovoltaic project in Sumba is part of the Sumba Iconic Islands (SII) project. SII project was introduced by Hivos, with the support of the Directorate General of New Renewable Energy and Energy Conservation (Direktorat Jenderal Energi Baru Terbarukan dan Konservasi Energi/ DJEBTKE), Ministry of Energy and Mineral Resources of the Republic of Indonesia (Kementerian Energi \& Sumber Daya Mineral/ESDM) in 2011. The programme is supported through the Energy and Mineral Resources Ministrial decree number 3051 K/30/ MEM/2015, designating Sumba as alternative renewable energy icon. Access to equitable green energy is the key to improve livelihood as well as environmental sustainability in Sumba.

Based on the study, Sumba Island has been chosen as the Iconic Island of $100 \%$ renewable energy because of its low access to energy with electrification ratio of only $24.55 \%$ in spite of the 
island's great renewable energy potential such as water, bioenergy, wind, and solar (Hivos, 2016). Funding of SII project among others come from several donors, including the Asian Development Bank (ADB), the Norwegian Embassy, the Millennium Challenge Account - Indonesia (MCA-I) through the Green Prosperity programme.

Solar photovoltaic installation for elementary school at Lewatidas, East Sumba is available since mid-April 2016 for the teachers and around 270 students at Kataka Elementary and Junior High Schools in isolated East Sumba district. Solar photovoltaic generate electricity about 1 $\mathrm{kWp}$ for lighting and their electronic equipment, such as handphone chargers, computers, laptops, printers, photocopier, and other audiovisual devices to support their teaching and learning activities. Students can also recharge their solar lamps at the E-Kiosk at school to help them study at night.

In 2015, solar photovoltaic (11 kWp) was also installed at Kamanggih village, East Sumba. The solar photovoltaic hybrid with 20 wind powers $(10,000 \mathrm{Watt})$ in that area. The electricity resulted from those energy technology can light up around 23 houses. Each house gets 3 gallows lights (125 Watt) and must pay about USD 2 per month. Although the energy technology was installed only for a few years, it has changed their live. Almost all households have electricity for lighting and electronic equipment, such as rice cooker and blender. Business in the community also grows, such as small business in handicraft, food processing, and groceries store. Educational process also changed more lively. Since the classroom has light, the teacher can give extra class until late afternoon and even at night for the prepation of national examination.

The advantages of this project was gained through a very comprehensive project planning and development done by Hivos and its partners. Many stakeholders took part since the beginning of the project. Almost all projects have very active communication among stakeholders and recipients of the project. The supports came not only from government, but also from many donors, private, as well as international donor agency.

\section{E. Wind turbine}

Sumba Island is located in Nusa Tenggara Timur Province, eastern part of Indonesia. The landscape is low and limestone hills. Sumba is also one of the poorest islands in Indonesia. Micro wind turbine is one of the energy technologies installed in 2013 in Kamanggih, one of isolated villages in the subdistrict of Kahaungu Eti, East Sumba Regency. Installation of 20 micro wind turbines in this area was done by NGO A with funding from CSR of Oil Company (PT Pertamina). Business management of these micro wind turbines were done by Kamanggih Cooperative. Each micro wind turbine has power of $500 \mathrm{Wp}$ at height 4 meters, blade diameter $1.6 \mathrm{~m}$. In the same place there is also solar panel $(1 \mathrm{~kW})$ for generating electricity.

Therefore, this area is electrified by windsolar hybrid system with total capacity of 11 $\mathrm{kWp}$. Wind-solar hybrid uses battery which can keep electricity for 3 days. Electricity generated from these technologies is used to light up to 23 households in the nearby areas. Every house has 3 gallows lights (total power $125 \mathrm{~W}$ ) without using the meter electricity kit ( $\mathrm{kWh}$ meter). Cost for 3 gallows lights is about Rp. 20,000 (USD $1.8)$ every month. They pay the electricity cost to Kamanggih Cooperative. Almost all households use electricity during night time, while at day time they spend time working in their field and plantations.

There are many benefits of having electricity in this area; the children can study at night and adults can continue working on their craft after the sun sets. In addition, by having electricity, clean water is easy to get since children and women do not spend much time to fetch clean water. Life does not need to stop when it is dark. Successful implementation of wind turbines in Sumba Island was done due to several factors, such as comprehensive project planning and development, support from local government and many stakeholders, as well as active community participation. The project managers also develop workshop, skills trainings, and good network among all stakeholders at national as well as international level. 


\section{DISCUSSION}

The following section describes the key success factors in implementing renewable energy projects in the rural community. Several key themes emerged in the analysis of data and these are outlined in the following sections. Besides availability of funding, there are six key factors influencing the success of renewable energy technologies projects in rural areas of Indonesia, namely (1) project planning and development; (2) community participation; (3) active communication with stakeholders and beneficiaries; (4) availability of maintenance scheme, workshop, and technicians; (5) project management and institutionalisation; and (6) local government and other stakeholders support and network development. These findings will be discussed as follows.

\section{a. Project planning and development}

The projects selected for this research largely have very comprehensive project planning and development. Project managers develop the baseline data (including defining scope, objectives, schedule, cost and benefits/users based on gender) and the project management plans, including for risk management. The managers also define the roles and responsibilities of the stakeholders involved in the project, including project sponsors, experts, managers, technicians, users, and others. Besides, the stakeholder meetings is held on a regular basis to build trust among the team members and ensure all ideas are taken into account. Analysing project quality and risks are accomplished together with monitoring and evaluation of the project, which are done regularly. The management for several projects had continued their monitoring and evaluation for several years after the technology was implemented.

\section{b. Community participation}

The study shows that the success of all projects depends on the level of community involvement. In all project samples of this study, communities are involved in almost all stages of the project, particularly in the operational and maintenance stage. The microhydro project in the provinces of
East Java and East Nusa Tenggara started their work with a comprehensive feasibility study. In this stage, the community was involved on a voluntary basis. The trust of the community in the project is the key for its commencement. Several project managers also provide support for the community - mostly in the form of capacity building, such as skills generation through training, which can be used afterward. For example, in the microhydro and biogas construction, community members are part of the installation team. Afterward, they can use their skills as a biogas digester constructor, which in turn can improve their income. After the implementation of each energy technology project, the authority of the project usually handed over the project to the community organisation or cooperative. This kind of participation can empower community.

Different communities have different needs, problems, beliefs, practices, etc. related to the use of clean energy for their daily life. Getting the community involved in program design and implementation helps ensure that strategies are appropriate for and acceptable to the community, including for women and children. Therefore, community participation can increase the accountability of renewable energy projects and programs.

\section{c. Active communication with stakeholders and beneficiaries}

Active communication among project implementers, supporting institutions, and project beneficiaries is very important. Through active communication, the implementers would get political support from the central and local government. Active communication usually occurred during regular meetings with beneficiaries, local government, and other institutions related to the project. In the meetings with the beneficiaries, communication was mostly related to the technology (such as how to operate it, maintain it, and other benefits of the technology), marketing, management of the technology, and other information that benefited the community (participants of the meeting). The project implementer also paid special attention in communication with the 
community and religious leaders since they are the most influential figures in the communities.

Almost all projects have what it is called community liaison officers (CLO). The CLO usually come from the locals who are trusted by the community and also has knowledge on the project. As a CLO, he or she will usually have first contact with the community and maintain communication throughout the project activities.

There are several criteria for selecting beneficiaries of the project. Besides low income or poor community or households as the beneficiaries, other criteria, such as ownership of cattles (pigs or cows), can be one of the criteria for a biogas grant eligibility. For the microhydro project, one of the criteria is the distance from the house to the microhydro power plant. For energy technology projects which required sharing funding between the implementers and the beneficiary, economic capability of the beneficiary could be taken into consideration. Almost all implementers used more than one criteria for selecting their beneficiaries. Without clear criteria, the project would not succeed and achieve its targets or even become excessively costly.

\section{d. Availability of maintenance scheme, workshops, suppliers, and technicians}

To make the technology energy project more sustainable, not only is the installation process crucial, but post-installation maintenance is also more important. In practice, many of the energy technology projects neglect this requirement. The implementing authority often does not plan for maintenance in the budget. However, in most cases, once the technology is implemented, it will need maintenance for the sake of its sustainability.

Another major concern about the sustainability of the project is the availability of good technicians, suppliers, and workshops. In the case of renewable energy technology projects, a skillful technician is needed as well as suppliers and a workshop for turbine maintenance or purchasing of spare parts, particularly post-implementation. Most of the microhydro turbine and spare parts suppliers are located in big cities, which are very far from the village where the turbine is implemented.
The challenge is: who should be responsible for maintenance and where should the funding come from? Although the implementing authority set up the project in the beginning, they never make long-term plans for the project. Therefore, the microhydro project management should allocate funding for this purpose. The funding should be allocated from their business, i.e. selling electricity from microhydro to the community. Many of the energy technology projects for community fail on the maintenance level. They never have a serious budget plan for maintenance, and consequently the energy technology cannot continue. For individual beneficiaries, such as biogas, maintenance will be done by the owner of the digester (household).

Together with maintenance activities, availability of workshops and technicians are very essential for all kinds of energy technology projects. The challenge is how to make local technicians and spare parts for the energy technology available all the time. In rural areas, not all local trained people are available all the time. Many young people migrate easily to other cities, islands, or even to neighbouring countries. Therefore, starting from the beginning, those who have been trained in certain energy technology should receive funding and technology facilitation. They can use their skills to assist in developing small businesses, such as opening a service technology workshop as well as selling spare parts for the energy technology.

\section{e. Project management and institutionalisation}

After implementation of the energy technology, the project owner or implementing authorities should have prepared to hand over the project to the community as the main beneficiary of the project. During the study, the researchers found that for project management which prepared management training for the community, the transfer of project management activities was easier when transferred to a trained community. For example, in the microhydro case, along with the installation of turbine, the management also organised or provided some training for the community, such as technical training as well 
as management training for microhydro. Later on they also helped the community in setting up the project's institution, such as a cooperative or community organisation. Developing a formal organisation to manage an energy technology project is strongly recommended since many of the project activities are intervened politically. The management of technology energy projects should cover all activities, including monitoring and evaluation activities.

\section{f. Local government and other stakeholders support and network development}

This study has clearly indicated that one of the success factors of the energy projects in these villages is the presence of strong relationships with other stakeholders, such as local government institutions, the local state-owned electricity company (PLN), small and medium companies and workshops that produce spare parts, local banks and other financial institutions, the local radio and other medias, NGOs, and universities. Communication as well as networking with those stakeholders should be maintained.

Through the Law on Local Government No. $32 / 2004$, local governments now play a greater role in administration. In all districts, the local government now effectively controls the development of energy resources and the issuing of permits for infrastructure projects, including land acquisition and procurement of the various necessary permissions for the implementation of the energy project. Networks with other stakeholders also provide many benefits for the project, such as access to funding as well as information (e.g. technology, funding, policies or legislation, market, etc). Networks also provide technology, grant funding, new investment initiatives or potential contracts, access to resources, access to expertise, training support, advice and political updates, and insight. All these things should be viewed as opportunities for the development of the project.

Other benefits of networks include more effective expansion of the market as well as increases in the skills of existing employees or technicians. Developing networks and maintaining relationships with other stakeholders will enable participation in numerous networking events, such as seminars, exhibitions, and workshops organised by other stakeholders and many that are free to attend. These are excellent opportunities to promote the project and build networks.

\section{CONCLUSION}

The sustainability of the renewable energy projects in this study is mainly driven by local concerns and not national policy. This means that the choice and scale of projects reflect local opportunities; in other words, mainly oriented to serve local demand. The types of renewable energy technology implemented in these areas are relatively mature technologies, such as heat from biomass (improved cook-stoves), smallscale hydro power (microhydro) as well as wind and solar photovoltaic. Daily project operation is managed by local communities in the form of cooperatives and other forms of intermediate institutions or community foundations.

Moreover, community participation can be effective for a number of reasons, such as to promote shared responsibility of the renewable energy project in that area, particularly between the implementing authority (owner of the project), which is usually a government institutions or private enterprise, and the community as the users and managers of the energy projects.

The study has identified the key success and influential factors in the implementation of renewable energy technologies in rural areas of Indonesia, namely (1) project planning and development; (2) community participation; (3) active communication with stakeholders and beneficiaries; (4) availability of technology maintenance scheme, workshop, and technician; (5) project management and institutionalisation; and (6) local government and other stakeholders support and networks development.

In Indonesia, rural areas can be remote and difficult to reach; therefore, it is important to have appropriate supporting infrastructure for the renewable energy systems, including skills training for local technicians to help in operating and maintaining the renewable energy systems. 


\section{ACKNOWLEDGEMENT}

This research is funded by the Development Budget of the Research Center for Science and Technology Development, Indonesian Institute of Sciences. The researchers would like to express their gratitude to all those who gave them the possibility to complete this paper, especially to all respondents in the study areas. Last but not least, they also would like to thank their friends, especially Dr. Ikbal Maulana and Mrs. Hartiningsih, also NGOs involved in this study for all data and suggestions to make this paper possible.

\section{REFERENCES}

ADB. (2015). Achieving universal access to electrification. Final Report for the Government of Indonesia. Jakarta. July.

Alvial-Palavicino, C., Garrido-Echeverría, N., Jiménez-Estévez, G., Reyes, L., \& PalmaBehnke, R. (2011). A methodology for community engagement in the introduction of renewable based smart micro grid. Energy for Sustain. Dev. 15(3), 314-323. (http://dx.doi. org/10.1016/j.esd.2011.06.007)

Büscher, C. \& Sumpf, P. (2015). "Trust" and "confidence" as socio-technical problems in the transformation of energy systems. Energy, Sustainability and Society, 5(1), 1-13. (http:// dx.doi.org/10.1186/s13705-015-0063-7)

Carlisle, N., Elling, J., \& Penney, T. (2008). A renewable energy Community: Key elements: $A$ reinvented community to meet untapped customer needs for shelter and transportation with minimal environmental impacts, stable energy costs, and a sense of belonging. Technical Report. NREL/TP-540-42774. National Renewable Energy Laboratory. 1617 Cole Boulevard, Golden, Colorado, USA.

De-Xin, H. (2016). Coping with climate change and China's wind energy sustainable development. Advances in Climate Change Research, 7(1-2), 3-9. (Available online at www. sciencedirect.com, https://doi.org/10.1016/j. accre.2016.06.003)

EEP Indonesia (2014). Bio-energy for a bright future: Energy and environment partnership with Indonesia 2011-2014. Jakarta: EEP Indonesia, November.

Hivos. (2016). Sumba iconic island: $100 \%$ renewable energy. Accessed on 2 July 2017 from http:// sumbaiconicisland.org/sumba-iconic-island100-renewable-energy/.
Heaslip, E., Costello, G. J., \& Lohan, J. (2016). Assessing good-practice frameworks for the development of sustainable energy communities in Europe: Lessons from Denmark and Ireland. Journal of Sustainable Development of Energy, Water and Environment Systems, 4(3), 307-319. (doi: http://dx.doi.org/10.13044/j. sdewes.2016.04.0024)

Hermawati, W., Thoha, M., Grace, N., \& Rosaira, I. (2010). Kajian implementasi dan pemanfaatan pembangkit listrik tenaga mini/mikrohidro (PLTMH) untuk peningkatan usaha produktif masyarakat pedesaan [A study of the implementation and utilisation of mini/microhydro power plants (PLTMH) in increasing productive efforts of rural communities]. Jakarta: LIPI Press.

Hermawati, W., \& Darmayana, D. (2010). Model kelembagaan PLTMH di Indonesia [An institutional model for microhydro project in Indonesia]. National Proceeding of Perteta. Soedirman University, Purwokerto.

Hermawati, W., Darmajana, D., Thoha, M., \& Rosaira, I. (2010). Strategi pengembangan usaha listrik berbasis PLTMH dalam kaitannya dengan pembangunan masyarakat pedesaan [A strategy in developing a business of electricity based on microhydro in relation to rural community development]. Jakarta: LIPI Press.

Herran, D. S., \& Nakata, T. (2008). Renewable technologies for rural electrification in Colombia: A multiple objective approach. International Journal of Energy Sector Management, 2(1), 139-154. (doi: http://dx.doi. org $/ 10.1108 / 17506220810859132$ )

Hoffman, S. M., \& High-Pippert, A. (2010). From private lives to collective action: Recruitment and participation incentives for a community energy program. Energy Policy, 38(12), 7567-7574. (https://doi.org/10.1016/j.enpol.2009.06.054)

Jackson, E. T. \& Kassam, Y. (1998). Knowledge shared: Participatory evaluation in development co-operation. Ottawa: International Development Research Centre.

Magnoni, S. \& Bassi, A. M. (2009). Creating synergies from renewable energy investments, a community success story from Lolland, Denmark. Energies, 2(4), 1151-1169. (https:// doi.org/10.3390/en20401151)

Ministry of Energy and Mineral Resources (MEMR). (2014). Handbook of energy \& economic statistics of Indonesia. Jakarta: MEMR.

Ministry of Energy and Mineral Resources (MEMR). (2016). 12.659 desa belum berlistrik, Sudirman Said: Tahun 2016 program "Indonesia Terang" 
harus berjalan. [12,659 villages unelectrified, Sudirman Said: 2016, the "Indonesian Light Program" has to be implemented]. Press release number: 00017.Pers/04/SJI/2016 on 8 March, 2016, (Available at http://ebtke.esdm.go.id/ post/2016/03/08/1149/12.659.desa.belum. berlistrik.sudirman.said.tahun.2016.program. indonesia.terang.harus.berjalan)

OECD. (n.d). Linking renewable energy to rural development. Executive Summary, Policy Brief, Paris, France.

Oteman, M., Wiering, M., \& Helderman, J. K. (2014). The institutional space of community initiatives for renewable energy: A comparative case study of the Netherlands, Germany and Denmark. Energy, Sustainability and Society, 4, 11.

Pillai, G. M. (2014) Indonesia national sustainable energy strategy report on enabling environment and technology innovation ecosystem for affordable sustainable energy options. A paper prepared for Asian and Pacific Centre for Transfer of Technology (APCTT) of the Economic and Social Commission for Asia and the Pacific (UNESCAP). Retrieved on 1 August 2016 from

http://www.unescap.org/sites/default/files/Indonesia $\% 20$ National $\% 20$ Sustainable $\% 20$ Energy\%20Strategy\%20Report.PDF.

Radhakrishna, R. (2012). Lighting up the lives of the rural poor. Appropriate Technology, 39(2), 40. (ABI/INFORM Complete)

Rogers, J. C., Simmons, E. A., Convery, I., \& Weatherall, A. (2008). Public perceptions of opportunities for community-based renewable energy projects. Energy Policy, 36(11), 4217-4226. (https://doi.org/10.1016/j.enpol.2008.07.028)

Sambodo M. T. (ed). (2015). Kemiskinan energi listrik. Memberi terang wilayah terpencil Indonesia [Poverty electricity energy: Providing light for the remote areas in Indonesia]. Jakarta: LIPI Press.

Schmidt, T. S., Blum, N. U., \& Wakeling, R. S. (2013). Attracting private investments into rural electrification - A case study on renewable energy based village grids in Indonesia. Energy for Sustainable Development, 17(6), 581-595.

Schneider, M., Schmidt, T. S. \& Hoffmann, V. H. (2010). Performance of renewable energy technologies under the CDM. Climate Policy, 10(1), 17-37.

Sui, X. (2013). East Asian energy community building: Modeled on the European way?. Journal of Global Policy Government, 2(2), 233-244. (doi: https://doi.org/10.1007/s40320-013-00370)

Tharakan, P. (2015). Summary of Indonesia's energy sector assessment. Asian Development Bank. December 2015, Page 7.

The World Bank. (2013). Menuju akses universal memasak bersih tanpa polusi [Towards universal access of clean cooking without pollution]. Jakarta: The World Bank.

Tomc, E. \& Vassallo, A. M. (2015). Community renewable energy networks in urban contexts: The need for a holistic approach. International Journal of Sustainable Energy Planning and Management, 08, 31-42

Walker, G., \& Devine-Wright, P. (2008). Community renewable energy: What should it mean?. Energy Policy, 36(2), 497-500. (http://dx.doi. org/10.1016/j.enpol.2007.10.019)

Walker, G., Devine-Wright, P., Hunter, S., High, H., \& Evans, B. (2010). Trust and community: Exploring the meanings, contexts and dynamics of community renewable energy. Energy Policy, 38(6), 2655-2663. (http://dx.doi. org/10.1016/j.enpol.2009.05.055)

Wilkins, G. (2002). Technology transfer for renewable energy. London: Earthscan Publications Ltd. 


\section{Appendix 1.}

Brief Summary of the Study Sample

\begin{tabular}{|c|c|c|c|c|c|}
\hline Type of energy & $\begin{array}{l}\text { Project custody } \\
\text { of technology }\end{array}$ & District (Location) & User & Organisers & Major benefits to user \\
\hline \multirow[t]{3}{*}{ Microhydro } & $\begin{array}{l}\text {-MEMR } \\
\text {-Community }\end{array}$ & $\begin{array}{l}\text {-Lumajang, East Java } \\
\text { Province }\end{array}$ & $115 \mathrm{Hhs}$ & Local foundation & $\begin{array}{l}\text { Access to affordable elec- } \\
\text { tricity }\end{array}$ \\
\hline & $\begin{array}{l}\text {-Regional Gov- } \\
\text { ernment } \\
\text {-PT PLN }\end{array}$ & $\begin{array}{l}\text {-West Lombok, West } \\
\text { Nusa Tenggara Prov- } \\
\text { ince }\end{array}$ & $200 \mathrm{Hhs}$ & Cooperative & $\begin{array}{l}\text { Creation of economic } \\
\text { activity }\end{array}$ \\
\hline & $-\mathrm{NGO} A$ & $\begin{array}{l}\text { - Southeast Sumba, } \\
\text { East Nusa Tenggara }\end{array}$ & 80 Hhs & Cooperative & $\begin{array}{l}\text { Increased awareness of and } \\
\text { performance in education, } \\
\text { environment and health }\end{array}$ \\
\hline \multirow[t]{2}{*}{$\begin{array}{l}\text { Innovative cook- } \\
\text { stove }\end{array}$} & -NGO Y & $\begin{array}{l}\text {-Kulon Progo, Yogya- } \\
\text { karta Province }\end{array}$ & 40 Hhs & $\begin{array}{l}\text { Household/ } \\
\text { Individual }\end{array}$ & $\begin{array}{l}\text { Healthy cooking environ- } \\
\text { ment, greater efficiency }\end{array}$ \\
\hline & - NGO Y & $\begin{array}{l}\text {-Palangka Raya, Cenral } \\
\text { Kalimantan Province }\end{array}$ & $100 \mathrm{Hhs}$ & $\begin{array}{l}\text { Household/ } \\
\text { Individual }\end{array}$ & \\
\hline \multirow[t]{2}{*}{ Biogas } & $\begin{array}{l}\text { - Hivos } \\
\text {-MEMR }\end{array}$ & $\begin{array}{l}\text { West Lombok, West } \\
\text { Nusa Tenggara Prov- } \\
\text { ince }\end{array}$ & $20 \mathrm{Hhs}$ & $\begin{array}{l}\text { Household/ } \\
\text { Individual }\end{array}$ & $\begin{array}{l}\text { Healthy cooking environ- } \\
\text { ment, greater efficiency }\end{array}$ \\
\hline & & $\begin{array}{l}\text { Sumba Island and } \\
\text { Malang, East Jawa } \\
\text { Province }\end{array}$ & 30 Hhs & $\begin{array}{l}\text { Household/ } \\
\text { Individual }\end{array}$ & \\
\hline \multirow[t]{2}{*}{$\begin{array}{l}\text { Solar Photovol- } \\
\text { taic }\end{array}$} & $\begin{array}{l}\text {-MEMR/ } \\
\text {-Regional Gov- } \\
\text { ernment }\end{array}$ & $\begin{array}{l}\text {-West Lombok, West } \\
\text { Nusa Tenggara Prov- } \\
\text { ince }\end{array}$ & $50 \mathrm{Hhs}$ & $\begin{array}{l}\text { Household/ } \\
\text { Individual }\end{array}$ & $\begin{array}{l}\text { Access to affordable elec- } \\
\text { tricity }\end{array}$ \\
\hline & & $\begin{array}{l}\text { - East Sumba Regency, } \\
\text { East Nusa Tenggara }\end{array}$ & $20 \mathrm{Hhs}$ & & $\begin{array}{l}\text { Creation of economic } \\
\text { activity }\end{array}$ \\
\hline Wind turbine & $-\mathrm{NGO} A$ & $\begin{array}{l}\text { - Southeast Sumba, } \\
\text { East Nusa Tenggara }\end{array}$ & $22 \mathrm{Hhs}$ & $\begin{array}{l}\text { Household/ } \\
\text { Individual }\end{array}$ & $\begin{array}{l}\text { Access to affordable elec- } \\
\text { tricity } \\
\text { Creation of economic } \\
\text { activity }\end{array}$ \\
\hline
\end{tabular}

Note:

MEMR: Ministry of Energy and Mineral Resources, Indonesia

PT PLN: State-owned Electricity Company

Hhs: Households

Appendix 2.

Indonesian Renewable Energy Resources Potential

\begin{tabular}{llll}
\hline Types & Resources & Equivalent value & Existing utilisation \\
\hline Hydro & 845.00 million BOE & $75.67 \mathrm{GW}$ & $4.2 \mathrm{GW}$ \\
\hline Geothermal & $219.00 \mathrm{million} \mathrm{BOE}$ & $27.00 \mathrm{GW}$ & $0.8 \mathrm{GW}$ \\
\hline Mini/Micro Hydro & $0.45 \mathrm{GW}$ & $0.45 \mathrm{GW}$ & $0.084 \mathrm{GW}$ \\
\hline Biomass & $49.81 \mathrm{GW}$ & $49.81 \mathrm{GW}$ & $0.3 \mathrm{GW}$ \\
\hline Solar & - & $4.80 \mathrm{kWh} / \mathrm{m}^{2} /$ day & $0.008 \mathrm{GW}$ \\
\hline Wind & $9.29 \mathrm{GW}$ & $9.29 \mathrm{GW}$ & $0.0005 \mathrm{GW}$ \\
\hline Uranium & $\begin{array}{l}24.112 \text { ton* e.q. 3 GW for } 11 \\
\text { years }\end{array}$ & - & - \\
\hline
\end{tabular}

*Resources only exist in Kalan region, West Kalimantan

Source: MEMR (2014) 
Appendix 3.

Renewable Energy Sources and Forms of Energy

\begin{tabular}{lllll}
\hline \multirow{2}{*}{ Energy source } & \multicolumn{3}{c}{ Form of energy } \\
\cline { 2 - 4 } & Light & Heat & Mechanical power & Electricity \\
\hline Solar & Sunlight & $\begin{array}{l}\text { Passive solar } \\
\text { Solar water heating } \\
\text { Solar drying }\end{array}$ & & Photovoltaics \\
\hline Wind & & Wind pump & Wind turbine \\
\hline Hydro & & Water mill & Water turbine \\
\hline Biomass & Flame & Combustion* & & Steam turbine \\
\hline
\end{tabular}

Note: * Combined heat and power (CHP) is an efficient way to generate heat and electricity

Source: Wilkins, G. (2002) 